\title{
ONLINE ENGINEERING EDUCATION: LEARNING ANYWHERE, ANYTIME*
}

\author{
John Bourne \\ Sloan Consortium \\ Franklin W. Olin College of Engineering \\ Babson College
}

Dale Harris

Sloan Consortium

Purdue University

Frank Mayadas

Sloan Consortium

The Alfred P. Sloan Foundation

\begin{abstract}
The emergence of worldwide communications networks and powerful computer technologies has redefined the concept of distance learning and the delivery of engineering education content. This article discusses the Sloan Consortium's quest for quality, scale, and breadth in online learning, the impact on both continuing education of graduate engineers as well as degree-seeking engineering students, and the future of engineering colleges and schools as worldwide providers of engineering education.
\end{abstract}

\section{KEYWORDS}

online education, virtual laboratories, online degrees

\section{INTRODUCTION}

\section{A. Defining the Landscape}

Education at a distance, as provided through correspondence courses and video media, has been largely supplanted by online education as the world's networking capabilities have become ubiquitous. Studying engineering online from anywhere and at anytime has become possible in recent years but is not yet widespread throughout all engineering education disciplines. For online engineering education to be broadly accepted and utilized, (1) the quality of online courses must be comparable to or better than the traditional classroom, (2) courses should be available when needed and accessible from anywhere by any number of learners, and (3) topics across the broad spectrum of engineering disciplines should be available. These three attributes-quality, scale, and breadth — form the basis of work of the Sloan Consortium, a group of more than 900 primarily United States based academic and corporate institutions [1] dedicated to making online education a part of everyday life.

The Sloan Consortium (Sloan-C) is an organization supported by the Alfred P. Sloan Foundation 
committed to making learning available to anyone, anywhere, anytime. Organizing and disseminating knowledge about online education, Sloan-C is a major supplier of information about online education. Focusing on quality, scale and breadth in online education, Sloan-C is constantly engaged in advancing knowledge about online learning. Membership includes universities and colleges in higher education, corporations, organizations, and individuals.

The landscape considered in this paper is largely confined to considerations about how engineering education can be offered online with quality, scale, and breadth. In this paper, the current state-of-the art from Sloan-C's viewpoint is discussed, along with a prospectus for the future of online engineering education.

\section{B. History}

Funding for online education commenced at the Sloan Foundation as a vision of Ralph Gomory [2] and Frank Mayadas [3] with the establishment in 1993 of the "Learning outside the classroom" program, now known as the "Sloan program in asynchronous learning, Anytime, Anywhere, Online" [4]. The Sloan Foundation has been a major force in online learning in the United States. Since the inception of the "Learning outside the classroom" program, the Sloan Foundation has pushed the field of online education forward through a program of directed philanthropy designed to jump-start online education, promote awareness of online education, spur improvements in the field and investigate knotty issues. Funding an online journal in the field and expending more than \$50 million for research and development, the Foundation's commitment to the field has made a real difference in what online education has become today. This difference can be readily measured in the increase in online learners, from nearly none ten years ago to well over 2 million learners online today.

More than a decade later, the vision of bringing education to anyone, anywhere has been partially realized as higher education begins to understand how online methodologies integrate with and extend traditional on-campus education. During the next decades, it is likely that traditional collegiate on-campus and online education will become more integrated (or blended) so that anyone, anywhere can secure the education of their choice from any institution or consortia of institutions. Blending between college settings and lifelong learning will also occur, making quality online education available to everyone throughout their lifetimes.

Engineering education has special needs when offered in a distance mode, including consideration of how best to provide laboratory experiences. This paper reviews activities that have the potential to move online engineering education forward during the upcoming decade and offers a perspective on how engineering education will adopt the broader vision of online education offered above.

Traditionally, engineering education has been content-centered, design-oriented, and permeated by the development of problem solving skills. More recently, team building and collaborative problem- based learning have been added. The amount of content deemed necessary for graduates of engineering degree programs has steadily increased over the last half century. The content continuously changes but often not without considerable debate in engineering faculty curriculum committees. What topics should be offered? Which are most important? How

can choice across a broad spectrum of engineering topics be provided? Which topics fit which degrees and why? How can online offerings be staffed and funded? In this paper, we argue that many of the issues raised because of tradition can be solved through collaboration among institutions to create a strong national shared engineering curriculum enabled by online methods. While online education may be primarily about offering to distance learners anywhere and at anytime, it may well play a remarkable role 
in bringing together the work of colleges and universities across the United States (and eventually across the world). Such collaboration will ultimately provide more choice and diversity of opportunity to learners with lower costs. For these reasons, online education will ultimately play a much greater role in changing higher education in the world than simply providing education at a distance. Collaboration, partnerships, and lowered costs for higher-quality educational products with higher learner satisfaction will become commonplace as a result of providing engineering education with quality, scale, and breadth.

Acceptance of online education as a major and viable component of higher education has grown dramatically [5], however this has not yet led to a significant increase in engineering degrees granted [6]. As a recent National Science Foundation (NSF) report notes [7], the pool of engineering graduates that supplies the engineering workforce is predicted to remain flat for the foreseeable future, even as the need for more engineers increases. Increasing the availability of online degrees in engineering and science can increase the number of qualified workers in the labor pool in these fields.

Yet, even with the need for growth, adopting the methods of quality online learning has been slow to take hold in engineering education. This paper reviews the status of engineering education online and provides an analysis of how to move the field forward. Barriers to acceptance are examined and solutions are proposed.

\section{THE STATUS OF ONLINE ENGINEERING EDUCATION}

Why has undergraduate engineering education lagged behind some other fields in adopting online methodologies? Some of the special needs of undergraduate engineering education have not been well served by methods of online education. Specifically, laboratories are a mainstay of engineering education, as are mathematical foundations and design tools. Laboratories $[8,9]$ are notably difficult to provide online because of the traditional desire for the direct operation of instruments. Similarly, course materials that require significant use of mathematics have not been as easy to implement as topics that require only text-based discussion. Likewise, design tools often require computing power and graphics that are not always readily available in distributed networked environments.

In the more than ten years that methods for online education have been studied, much has been learned [10]. Prior to that time, distance education was limited to correspondence courses and televised lectures, although research about using computers in education had been actively pursued for some decades [11, 12]. Much of this work is reviewed in an earlier paper by the authors [13]. Indeed, the study of online engineering education methodologies has been conducted both in the United States and throughout the world [14], but is by no means completely understood today.

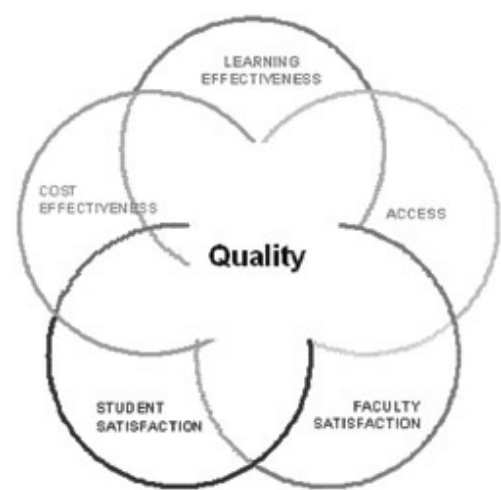

Figure 1. The five pillars of online learning. 
Five pillars of quality online learning have been adopted by the Sloan Consortium as a means for creating explicit metrics for online education and gauging progress in the field. Learning effectiveness, student satisfaction, faculty satisfaction, access, and cost effectiveness are the five metrics that drive investigations into online education. In the early years, problems in access were due largely to lack of connectivity; those problems have been largely solved. Still, many substantive issues remain as access is redefined as gaining attention share, providing optimum modalities to specific classes of learners or as new channels for providing knowledge. Significant progress has been made in learning effectiveness in such areas as social interaction and the creation of learning communities. Similarly, student satisfaction has been addressed as well as faculty satisfaction (support, rewards, and personal satisfaction). Costs for creating and running online courses have plummeted over the decade. The average expense per course created in awards from the Sloan Foundation to universities and colleges for creating online degree programs has continuously decreased over time. Other cost-related issues and practices [15] relate to administrative effort, reducing the call on classroom space, how students interact with faculty, etc. These issues are addressed historically over a period of years in the Sloan-C Elements of Quality Online Education series [16], which is published as an outcome of an annual research workshop sponsored by the Sloan Foundation. An aim of using five pillars is to define quality of online program offerings as an overlapping quintuple of metrics (see Figure 1) that can be tuned to fit an individual institution.

In sum, tremendous progress has been made in understanding how students learn effectively in online venues, how to improve the satisfaction of participants, how to enhance and create new channels for access, and in understanding the associated costs.

\section{A. Misconceptions}

A common misconception is that online education is a solitary, non-instructor-led, self-paced activity. Nothing could be further from the truth! Why this mantra has penetrated the consciousness of the engineering education professoriate is unclear. Correcting this misperception requires an understanding of how modern quality online education is a vital people-oriented, instructor-led activity with remarkably high communication attributes compared with much on-campus engineering education. In this paper, we make the case that online education can achieve certain goals that are difficult to achieve in face-to-face education.

A second popular misconception is that online education is solely about the application of technology to teaching and learning. To some degree this is true-online education is enabled by technology but is not specifically about technology. A more accurate description is that online education is about quality, scale, and breadth, as mentioned earlier.

\section{B. Research Evidence}

There is a long history of research in the literature about the use of technology to support teaching and learning. While technology is not always directly relevant to the issues of quality, scale, and breadth, research in applying technological advances to education provides a context for understanding the evolution of research in online education. Education provided by television has been used for many years [17], but until the invention and growth of the Internet, it was not possible to provide education to anyone, anywhere. There were mixed pedagogical results from the use of interactive television to provide classrooms at a distance [17]; various studies emerged, including investigating the use of laptops [18], multimedia [19], and building courseware [20], for example. While early research often lacked cohesion and a unifying direction, the work created a body of knowledge that has facilitated significant advances in online education. 
The Internet provided a rich new medium for teaching and learning that has evolved over the last decade, producing research results that have propelled us closer to understanding how to use Internet-based methods effectively. Several major research findings in the field are as follows [23]:

- There are no significant differences in learning outcomes for online and on-campus students as measured by test scores. The overwhelming evidence to support this claim can be found in the many research studies reported over the last decade in the Journal of Asynchronous Learning Networks (JALN).

- Social presence [21] (i.e., the social connectivity between learners, including instructors) is a key determining factor in whether people learn well online.

- Constructivist approaches [22] (i.e., learning approaches in which learners construct their own knowledge) work well online.

- Those who wish to learn online can do so, given the current state of the Internet and technical delivery mechanisms.

- Costs for delivery of online courses are comparable to oncampus education, and online course sizes are more scalable.

- Faculty are satisfied with online education.

- Students are successful in learning online and are typically pleased with their experiences.

\section{Examples from Engineering Education}

Until recently, there were few completely online courses in engineering. The 2003 national study of online education, "Sizing the Opportunity" [5], showed significant increases in the number of online programs at institutions, unfortunately it did not detail the numbers of programs or courses by discipline. The American Society for Engineering Education (ASEE) estimates [24] that there are more than 300 colleges of engineering offering engineering education in the United States. Most of the universities in which these colleges reside offer online education. Although it is not known well to what extent online education has penetrated each of these colleges, we gained some insights by analyzing the grants from the Sloan Foundation programs and asking the members of the Sloan-C listserv to contribute their knowledge. We present below some examples of programs that were jump-started through funding from the Sloan Foundation:

- In 1993, Northern Virginia Community College began work on a two-year online engineering degree [25], which resulted in an A.S. degree in engineering.

- The University of Illinois built in 1993 a collaborative learning environment around "Circuit Tutor," a self-paced learning system for teaching students about circuits.

- Vanderbilt University investigated a circuit tutor in the early 1990s (electronic laboratory simulator) in conjunction with California Polytechnic at San Luis Obispo, Rose-Hulman Institute of Technology, and Northern Virginia Community College [26, 27].

- In the mid-1990s, the University of Minnesota created two online learning courses in electrical engineering.

- Stanford was first funded by the Sloan Foundation in 1994 to create an M.S. in electrical engineering that would include video-on-demand services. In the decade since then, the Stanford program has blossomed and now offers a variety of online programs, including master's degree programs in electrical engineering, computer science, mechanical engineering, biomedical informatics, and management science and engineering.

- Georgia Tech developed an online master's-level degree in the late 1990s in mechanical engineering. Georgia Tech utilized the lecture-on-demand paradigm pioneered at Stanford, which is also used extensively at the University of Florida and other institutions. 
- The University of Washington created an online master's degree in heavy construction engineering as well an online master's-level degree program in computer science and a variety of degree programs in other engineering disciplines.

- Texas Tech University has been working toward increasing enrollments in online engineering degree programs, with programs ranging from engineering management to software engineering and petroleum engineering.

- Oregon State University has offered M.S. and certificate programs in software engineering.

- Pennsylvania State University has created several online engineering-related degree programs, including a Master of Engineering in Oil and Gas Engineering Management and a master's degree in geographic information systems [28].

- Stevens Institute of Technology offers a broad range of engineering offerings online, often with appealing nontraditional names.

- At the New Jersey Institute of Technology, a B.S. in Information Technology is offered as well as a complete engineering management degree at the master's level. Certificates in Project Management and Telecommunications networking are also offered [29].

- Pennsylvania State University offers one degree program in engineering and several postbaccalaureate certificates in specialty areas such as noise control and architectural lighting through the PSU World Campus [30].

- On the for-profit side, the National Technological University (NTU) offers degree programs in many engineering disciplines at the master's level. NTU, acquired in 2002 by Sylvan Learning Systems, has a rich history of delivering master's degrees in engineering. The NTU model has changed from a video download/tape methodology to a largely asynchronous model in which faculty are assisted by instructional assistants (IAs) — super TAs.

- The University of Michigan offers three M.Eng. programs online: Master of Engineering in Automotive, Manufacturing, and Integrated Microsystems. Core courses in engineering provide breadth, specialty courses provide depth, and two to three management and human factors or business courses and a project provide a thirty-credit degree program [31].

- Worcester Polytechnic Institute offers online graduate degrees and certificates in fire protection engineering and environmental engineering [32].

Table 1 provides a sample of the engineering education activities from the Sloan-C catalog [33]. This catalog is a reviewed listing of more than 600 online degree and certificate programs offered by Sloan-C members.

\begin{tabular}{|l|l|l|}
\hline Degree Title & School & Degree \\
\hline $\begin{array}{l}\text { Aeronautical Science in Space } \\
\text { Studies }\end{array}$ & Embry-Riddle Aeronautical University & Master \\
\hline Automotive Engineering & University of Michigan & Master \\
\hline Aviation Safety Management & Saint Louis University & Master \\
\hline Biomedical Informatics & Stanford University & Master \\
\hline $\begin{array}{l}\text { Engineering Management; } \\
\text { Project Management }\end{array}$ & Drexel University & Certificate \\
& Drexel University & Master \\
& Kansas State University & Master \\
& New Jersey Institute of Technology & Master \\
& University of Colorado at Denver & Master \\
& Texas Tech University & Master \\
\hline
\end{tabular}




\begin{tabular}{|c|c|c|}
\hline & Stanford University & Master \\
\hline Chemical Engineering & Kansas State University & Master \\
\hline Civil Engineering & Kansas State University & Master \\
\hline Computer Networking & $\begin{array}{l}\text { New Jersey Institute of Technology } \\
\text { Stevens Institute of Technology }\end{array}$ & $\begin{array}{l}\text { Certificate } \\
\text { Master }\end{array}$ \\
\hline Computer Science & $\begin{array}{l}\text { University of Illinois - Urbana } \\
\text { Champaign } \\
\text { Stanford University }\end{array}$ & $\begin{array}{l}\text { Master } \\
\text { Master }\end{array}$ \\
\hline Construction Management & University of Washington & Certificate \\
\hline Digital Signal Processing & Stevens Institute of Technology & Certificate \\
\hline Electric Power Technology & Bismark State College & Associate \\
\hline $\begin{array}{l}\text { Electrical and Mechanical } \\
\text { Engineering Technology }\end{array}$ & Rochester Institute of Technology & Bachelor \\
\hline Electrical Engineering & $\begin{array}{l}\text { University of Illinois } \\
\text { Kansas State University } \\
\text { Fairleigh Dickinson University } \\
\text { Colorado State University } \\
\text { Stanford University }\end{array}$ & $\begin{array}{l}\text { Master } \\
\text { Master } \\
\text { Master } \\
\text { Master } \\
\text { Master }\end{array}$ \\
\hline Engineering & $\begin{array}{l}\text { University of Illinois at Chicago } \\
\text { Texas Tech University }\end{array}$ & $\begin{array}{l}\text { Master } \\
\text { Master }\end{array}$ \\
\hline Fire Protection Engineering & Worcester Polytechnic Institute & Master \\
\hline $\begin{array}{l}\text { Heavy Construction Project } \\
\text { Management }\end{array}$ & University of Washington & Certificate \\
\hline $\begin{array}{l}\text { Human Factors in Aviation } \\
\text { Systems }\end{array}$ & Embry-Riddle Aeronautical University & Master \\
\hline Information Systems & New Jersey Institute of Technology & Certificate \\
\hline Petroleum Engineering & $\begin{array}{l}\text { Texas A\&M University } \\
\text { Texas Tech University }\end{array}$ & $\begin{array}{l}\text { Master } \\
\text { Master }\end{array}$ \\
\hline Geographic Information Systems & University of Colorado at Denver & Master \\
\hline Computer Systems/Software & $\begin{array}{l}\text { University of Maryland University } \\
\text { College } \\
\text { Oregon University System } \\
\text { Kansas State } \\
\end{array}$ & $\begin{array}{l}\text { Master/Certificate } \\
\text { Certificate } \\
\text { Master } \\
\end{array}$ \\
\hline Mechanical Engineering & $\begin{array}{l}\text { Georgia Institute of Technology } \\
\text { University of Illinois - Champaign } \\
\text { Stanford University }\end{array}$ & $\begin{array}{l}\text { Master } \\
\text { Master } \\
\text { Master }\end{array}$ \\
\hline Photonics and Optoelectronics & University of Massachusetts - Lowell & Certificate \\
\hline $\begin{array}{l}\text { Power Plant Technology/Process } \\
\text { Plant Technology }\end{array}$ & Bismark State College & Associate \\
\hline Manufacturing & University of Michigan & Master \\
\hline Statistical Quality & Rochester Institute of Technology & Certificate \\
\hline $\begin{array}{l}\text { Civil Engineering: Structural } \\
\text { Design }\end{array}$ & Rochester Institute of Technology & Certificate \\
\hline Telecommunications Engineering & Rochester Institute of Technology & Master, Bachelor, \\
\hline
\end{tabular}




\begin{tabular}{|l|l|l|}
\hline Technology & & Certificate \\
\hline Technical Administration & Franklin University & Bachelor \\
\hline
\end{tabular}

Table 1. Online engineering-related degrees offered in the Sloan-C catalog (as of fall 2004).

\section{Comparing Online and Traditional On-Campus Degrees}

From the above list of degree programs, it is apparent that most online engineering education is at the master's and certificate levels. Limited activity has been noted at the Ph.D. and the pre-engineering level (associate's degrees, for example). Work on creating complete undergraduate degree programs in mainline engineering disciplines is underway. For example, the University of Washington is considering the creation of bachelor's programs online in engineering [34].

Lack of significant online activity beyond the certificate and master's levels is likely due to (1) the need in traditional engineering programs for hands-on undergraduate laboratories and (2) the current engineering education culture at the B.S./B.E. level. On-campus education and online education have the potential to supply similar levels of interaction and capability in most engineering education areas. However, each degree type has had special difficulty or ease in entering the online venue:

- Pre-engineering and the first two years of an undergraduate engineering degree are heavily oriented toward basic mathematics and science. Since mathematics and science courses have lagged somewhat in online venues, the lack of widespread availability of these courses is a likely impediment to implementing fully online engineering degree programs. Interestingly, the highly successful Stanford program for gifted and talented students (Education Program for Gifted Youth, EPGY) [35] has been able to capitalize on online learning and has enrolled more than 3,000 students in the program. It would be reasonable to adapt methods from such pre-college programs to higher education.

- A hallmark of undergraduate engineering education is laboratories. Although several studies [26, 27] have shown similar learning effectiveness in virtual and remote laboratories, their adoption remains low. While remotely controlled physical laboratories would be fairly expensive to implement online, cost savings could ultimately be appreciable if high-cost instrumentation could be shared among institutions. If interactivity in online laboratories can be improved, undergraduate engineering educators may adopt online laboratories methods more readily.

- Graduate engineering education normally does not have significant barriers to entry. There are few perceived barriers for implementing online programs since laboratories are often not a major part of graduate education and a degree can be completed by taking about eight or ten semesterlong courses.

- Certificate programs are prevalent because of the ability to concentrate in a specific area and the brevity of most programs.

\section{THE NEEDS OF ENGINEERING EDUCATION}

Engineering education has traditionally had various delivery-centered constraints. Online methodologies will ultimately assist in equipping graduates to learn more broadly and deeply and to become lifelong learners.

\section{A. The Rationale and Need for Degree Programs}

Most online degree programs in engineering are currently offered at the master's level, presumably 
because of the need among working engineering professionals for master's-level degrees. Finding it more difficult to access campus-based-learning, these professionals may find the convenience of online education to be the most valued aspect of online learning. A good reason for colleges to offer online engineering degrees at the master's level is that these programs typically require only a modest number of semester hours (or equivalent), e.g., thirty semester hours. The typical B.S. degree in engineering requires more than four times as many semester hours, thus presenting a significant implementation barrier for complete programs. Further, fewer laboratories are needed at the master's level since students usually acquire basic skills in their undergraduate education.

To satisfy the need for more trained engineers in the workforce, there might logically be a greater need for online B.S. degrees in engineering than for higher-level degrees if the number of degrees awarded at both levels adheres to historical patterns [36]. However, the trend for producing proportionately more master's degrees coupled with the ability of engineering departments to offer shorter, less-constrained graduate degrees (i.e., not requiring undergraduate accreditation) argues for an increase in online degrees offered at the master's level. Currently, few colleges have created online B.S. degree programs. Nevertheless, there is a clear potential for creating such degrees across multiple institutions through shared resources. By sharing resources (remote laboratories and curricula online), the high costs associated with delivering bachelor's degrees can be reduced. This potential may remain unrealized, however, until there is additional pressure for improving breadth and scale in engineering programs.

\section{B. What is Different about Engineering Education?}

Are there significant differences between engineering education and other disciplines, such as the liberal arts, that make engineering difficult to teach online? Engineering education is science and mathematics based-subjects that are traditionally the hardest to teach online because of the need for laboratories and equation manipulation. In the early years of online education, equations were hard to deploy because of limitations in technology. That problem has now been solved, to some degree, with current tools [e.g., 37, 85]. Nevertheless, the appeal of the physical blackboard (or whiteboard) is unlikely to disappear from engineering education anytime soon. With regard to laboratories, the problem is difficult because one must be able to provide hands-on experiences at a distance. Virtual hands-on laboratories can be added to online engineering education by providing laboratory resources at a distance that can be manipulated remotely. Expensive laboratory equipment maintained at one location, accessed by all, would have appeal to the online engineering teaching community [38]. Some institutions have addressed the laboratory problem through summer programs for hands-on access [39]. Students working at a distance and assembling in person for laboratory sessions may provide a good method for blending online learning with hands-on laboratories.

\section{Building Graduates Who Are Lifelong Learners}

Traditional, engineering curricula have been designed to provide what engineering students need to know, with the what referring to content. Learning to learn has been less emphasized, yet is part of the ABET engineering accreditation requirements [40]. Online education can assist in learning to learn since students learn the way they will learn the rest of their lives.

\section{ACCREDITATION: COMPARING ON-CAMPUS TO ONLINE}

Online methods can augment the ABET engineering competencies [40], as summarized in Table 2. Some competencies are clearly augmented more by online methods than others. For example, student writing abilities should be enhanced since writing is a critical element in communicating online; further, lifelong 
learning abilities should be enhanced since online education should be available throughout graduates’ lifetimes.

\begin{tabular}{|c|c|}
\hline Competency & Potential Value Added by Online Education \\
\hline $\begin{array}{l}\text { (a) An ability to apply knowledge of } \\
\text { mathematics, science and engineering. }\end{array}$ & $\begin{array}{l}\text { Working with real problems in companies at a distance. } \\
\text { Increases availability of problems particularly to remote } \\
\text { locations. }\end{array}$ \\
\hline $\begin{array}{l}\text { (b) An ability to design and conduct } \\
\text { experiments, as well as to analyze and } \\
\text { interpret data. }\end{array}$ & $\begin{array}{l}\text { Experimental skills could be improved with access to } \\
\text { remote resources that might otherwise not be available. }\end{array}$ \\
\hline $\begin{array}{l}\text { (c) An ability to design a system, } \\
\text { component or process to meet designed } \\
\text { needs. }\end{array}$ & $\begin{array}{l}\text { Working in distributed design teams at different colleges, } \\
\text { working with selected industries would enhance the } \\
\text { learning experience. }\end{array}$ \\
\hline $\begin{array}{l}\text { (d) An ability to function on } \\
\text { multidisciplinary teams. }\end{array}$ & $\begin{array}{l}\text { Online methods can more easily provide the capability of } \\
\text { merging non collocated groups - e.g., adding students at a } \\
\text { business school. }\end{array}$ \\
\hline $\begin{array}{l}\text { (e) An ability to identify, formulate and } \\
\text { solve engineering problems. }\end{array}$ & $\begin{array}{l}\text { Capturing knowledge, methods and legacy can be a } \\
\text { formidable enhancer of applicative competencies. Online } \\
\text { methods permit adding real-world experiences that will } \\
\text { assist students to identify, formulate and solve problems. }\end{array}$ \\
\hline $\begin{array}{l}\text { (f) An understanding of professional and } \\
\text { ethical responsibility. }\end{array}$ & $\begin{array}{l}\text { An understanding through online case studies, including } \\
\text { more easily reaching real people who have had ethical } \\
\text { problems, would be a benefit to understanding. }\end{array}$ \\
\hline (g) An ability to communicate effectively. & $\begin{array}{l}\text { Online education will assist in writing (asynchronous } \\
\text { systems) and speaking (synchronous systems). }\end{array}$ \\
\hline $\begin{array}{l}\text { (h) The broad education necessary to } \\
\text { understand the impact of engineering } \\
\text { solution in a global and societal context. }\end{array}$ & $\begin{array}{l}\text { The internet provides an increasingly global capability for } \\
\text { people to work and learn together. It is essential to cast } \\
\text { education in the milieu in which life-long learners of } \\
\text { engineering will find themselves working throughout their } \\
\text { careers. }\end{array}$ \\
\hline $\begin{array}{l}\text { (i) A recognition of the need for, and an } \\
\text { ability to engage in life long learning. }\end{array}$ & $\begin{array}{l}\text { Learning to learn in off-campus modalities while still on } \\
\text { campus will greatly assist the transition to life-long } \\
\text { learning. }\end{array}$ \\
\hline (j) A knowledge of contemporary issues. & $\begin{array}{l}\text { Integration with the internet-enabled world permits } \\
\text { combining education with current knowledge. }\end{array}$ \\
\hline $\begin{array}{l}\text { (k) An ability to use the techniques, skills, } \\
\text { and modern engineering tools necessary for } \\
\text { engineering practice. }\end{array}$ & $\begin{array}{l}\text { Many engineering tools are internet-based. Online students } \\
\text { will adapt easily to learning and using these tools and be } \\
\text { prepared for their utilization in engineering practice. }\end{array}$ \\
\hline
\end{tabular}

Table 2. Potential value added to ABET engineering competencies by online methods.

\section{A. Pedagogy to Improve Competencies}

Lectures are frequently used in engineering education to transmit information to students. In an online learning environment, lectures can be captured and replayed anywhere, anytime, thus providing enhanced flexibility for learning. Libraries of stimulating presentations can be captured, cataloged, and reused again and again [41], thus contributing to, for example, competency (b) in Table 2. Experts can be easily 
brought into the online classroom, enabling learning experiences that are not as readily acquired in a traditional on-campus classroom (competencies b, c, d, h, j). These types of improvements are applicable in several of the competencies listed in Table 2, especially those that prepare students for a lifetime of learning.

While multiple disciplines have moved toward experiential learning as a core education methodology, progress on injecting more real-world experiences into the typical engineering undergraduate experience has been somewhat limited (competency a). Hands-on experiences in engineering education are typically provided through laboratories and field experience. However, laboratories require a high investment in both equipment and instructor time, and field experience is often limited. Some engineering colleges have attempted to move to more integrated and constructivist experiences [42], but change is difficult. In online education, pedagogy can be improved through building a community of learners (e.g., competencies e, d, g, h, i) who achieve swift trust [43] among teams that are able to work together to achieve learning goals in near-real-world settings. Moving engineering learners into settings in which the connection to the real world is continuously present will help achieve some of the major accreditation goals listed above. However, achieving such improved pedagogy through connectivity will be difficult given today's somewhat rigid technology barriers (e.g., widely used online course management systems, connectivity and firewall issues, etc.). Fortunately, flexible course management systems are being created that will enable constructivist and experiential online education learning paradigms, including distributed team learning [44].

\section{B. Attracting and Retaining Students in Engineering}

Anecdotal evidence suggests that students who are attracted to engineering are those in high school who excel in mathematics and science; many have enjoyed creation and experimentation. These students are often good with computers; some enjoy tinkering; many are musical. The high levels of organization and creativity in prospective engineering students argues for a curriculum that permits choice, diversity, creativity, and connection with many fields. Yet, typical engineering curriculum requirements of mastering an ever-increasing amount of pure engineering content are antithetical to these attributes. Online engineering education degrees, supplied by partnerships among multiple institutions, can permit increasing choice, diversity, creativity, and connection and hence can be a useful pathway for engineering education to follow. Online education permits more flexible course offerings shared among institutions. This enhanced flexibility could well occur in tiers, with coalitions being formed among institutions with similar missions. Thus, institutional groupings that attract students to engineering and deliver the competencies listed above in online environments may break out in tiered groupings. For example, some college coalitions may be able to provide connections to various industry segments more readily than others, while other groupings may be able to specialize in making connections to the arts, sciences, and a multitude of other topics. Others might specialize in remediation. Much progress in these directions was made by the Engineering Education Coalitions [45]. Strategies for differentiation among institutions and institutional groupings will likely emerge more strongly to attract and retain students.

To retain students, interest, opportunity, and progress must be maintained. Interest can be increased through online methods by providing access to a richer and broader set of learning experiences. Opportunity can be increased by integrating the engineering education learning platform with continuous learning and connection to the real world. Improved progress toward degrees can be achieved by opening more learning pathways. For example, if a course is not available at one school, online courses from tiered partner schools could be substituted almost transparently. Institutions will need to understand more clearly the needs of their students [46] and adapt offerings and methods to those they wish to serve. For example, the specific needs of women need to be more fully studied, both on campus and online [47]. 
Engineering has the reputation of being one of the more difficult disciplines to master. Since mastery of a body of constantly changing knowledge is impossible to achieve, this perception is warranted. However, an alternative and complementary view of engineering education is that its purpose is to create graduates who can evolve seamlessly into a mode of lifelong learning. While this argument has been made for years, the capability to realize the opportunity via online education has not existed before. Retention problems are likely to disappear when undergraduate education is seen by colleges as the first step in the continuous pathway in lifetime education.

\section{Continuing Education}

The emergence of the global knowledge economy is placing increasing importance on lifelong learning. Continuing education is defined as formal education beyond the bachelor's degree other than the traditional master's and doctorial programs. Some may continue to distinguish between education and training. In this view, education is a broader learning experience covering a field of study, whereas training targets specific skills and job activities. In the knowledge economy, this distinction quickly breaks down. In engineering, yesterday's education can become today's training overnight. Consequently, the two types of learning converge, or at least create an ever expanding gray area. It is in this expanding gray area that modern continuing engineering education organizations operate. This dynamic leads to significant changes in educators, learning institutions, and private industry and the relationships among them.

Continuing education is characterized by the circumstances of the learners and by the educational methodologies with which they engage. Continuing learners are typically employed professionals who expect to learn by doing and by learning from one another, as well as from an instructor. They expect to have unique, individual learning plans customized to their own goals and current knowledge base. Thus, the convenience of anywhere, anytime learning provides options not available through traditional classroom-based instruction. Since continuing learners are most typically interested in developing jobrelated knowledge or skill, the flexibility of online content development brings particular value to this group of learners. The goals of continuing education students are to improve their ability to perform their current job, to develop the skills necessary to perform more complex and varied tasks, and to prepare for promotions and leadership positions. From the employer's viewpoint, advantage is gained from "just in time learning." Further, governments are recognizing that education continued throughout an individual's lifetime is a critical factor in the modern economy [48]. Web-based delivery makes such continuing education goals not only realistic, but mandatory.

Continuing engineering education programs are positioned between two extremes. At one extreme, continuing education programs blend with traditional degree-based programs. For example, courses developed for on-campus degree seekers are often slightly modified and repurposed as a short course offered to industry professionals. At the other extreme, corporations contract with university faculty or for-profit vendors to develop continuing education content specific to their requirements. Traditionally, universities have been reluctant to develop the industry- or company-specific content most needed in continuing education. This is gradually changing. As an example, the Stanford Advanced Project Management (SAPM) Program targets professionals managing, or preparing to manage, complex projects [49]. It is a collaborative program among Stanford University faculty, IPSolutions (a global industry consultant), and an advisory board of industry leaders. SAPM is a good example of a blended learning designed to suit the needs of professionals and their organizations. To obtain the certification, students must elect and complete six of twelve available professional education courses. Courses may be taken on campus, online, onsite at a company, or in any combination. SAPM enrollments have multiplied over the past three years and are expected to show a 30 percent growth this year and next. Another example of flexibility and collaboration is Purdue University's Master of Science in Engineering (M.S.E.) degree 
[50]. This degree, which is not available to traditional on-campus students, is composed of an interdisciplinary curriculum with no core courses. Corporate clients such as General Motors use the M.S.E. program as a base to design collaborative courses with Purdue faculty and other universities, assuring an integrated graduate education for their employees while they continue working. Purdue has also developed a customized master's program in quality systems engineering with Rolls-Royce and a dual M.S.E.-M.B.A. degree in partnership with Indiana University’s Kelley School of Business.

Finally, an increasing share of continuing education is provided by corporate universities. Such institutions were a rarity only twenty years ago and now number more than 2,000 [51]. Included in the list are IBM, Charles Schwab, Disney, Microsoft, Oracle, General Electric, McDonald's, Sears, Mastercard, Motorola, Toyota, Volvo, Sun Microsystems, Xerox, Cisco, and GM. Among the most ambitious is Motorola University [52], which has more than a thousand full- and part-time faculty and training specialists located in over twenty countries and more than 100,000 students per year. Some corporate universities are expected to provide or market their educational resources beyond the corporation itself. As an example, Motorola offers open enrollment to e-learning and certification services through Motorola University [52]. Cisco Systems offers extensive education and certification through its Cisco Networking Academy [53], which currently offers e-learning programs in more than 150 countries.

The purpose of corporate universities is to design and deliver cost-effective learning in direct support of corporate goals and strategies. These corporate organizations are responsible for determining the educational needs of the company, developing or purchasing content, determining and managing the delivery process including the technology platform, and offering education planning services to employees. Some corporate universities are nearly 100 percent Web-based and almost all have some Web-based elements. An estimated 50-75 percent of corporate education is now Webbased. Corporate universities are supported by a growing industry of vendors and content providers. Many well-known consulting groups, including Anderson, Price Waterhouse, and Corporate University Exchange, stand ready to assist corporate universities in planning, establishing, and maintaining their operations.

In addition to traditional universities, well-known for-profit content vendors targeting corporate universities include Blackboard. com, Caliber, Digital Think, Semizone, and Sylvan Learning Systems. As an example, Semizone [54] is a for-profit company that develops and delivers online technical content to industry clients in the semiconductor sector and related fields. Some of its online content is produced by faculty at Stanford University, who receive equity in Semizone as one portion of their compensation. The university is also a minority shareholder of the company.

All of the above examples demonstrate new forms of cooperation and relationships among universities, university faculty, and corporate interests facilitated by the advent of anytime, anywhere learning. This type of learning may find its greatest influence through continuing education. Not only the methods of delivery are being changed by the advent of the Internet, but the relationships among faculty, universities, and a varied array of corporate entities are now in flux.

\section{Laboratories}

One of the distinguishing elements of engineering education is the lab requirements. The current ABET engineering criteria states that all engineering programs must demonstrate that their graduates have an ability to:

- design and conduct experiments, as well as to analyze and interpret data;

- design a system, component, or process to meet desired needs; and 
- use the techniques, skills, and modern engineering tools necessary for engineering practice.

The criteria further state that:

- classrooms, laboratories, and associated equipment must be adequate to accomplish the program objectives and provide an atmosphere conducive to learning; and

- the program must include college-level mathematics and basic sciences (some with experimental experience) appropriate to the discipline.

In 2002, with funding from the Alfred P. Sloan Foundation, thirteen objectives for engineering class lab sessions were drafted by ABET in consultation with thirty-five educators from thirty-one institutions offering engineering degrees. Details of this process and its outcomes were first reported in [9] and are described in detail by Feisel and Rosa [55] in this issue.

It is generally accepted that some of these thirteen criteria may be met as easily online as in a campus lab environment [56]. These criteria include communication skills, teamwork, and ethics. For others, such as psychomotor and sensory awareness, it may be difficult, if not impossible, to equate the online experience with that of a campus lab. It is also accepted that effective online labs will be more easily developed for some engineering disciplines, software engineering for example, than for others, such as chemical engineering.

A current research problem is to demonstrate that the thirteen conditions can be met to a sufficient degree online to support accreditation. The solution holds importance for distance-delivered as well as campusbased programs [57]. Online access to labs has the potential to reduce equipment costs on campus and even to allow sharing of specialized equipment between institutions [58-60]. Examples of online laboratory Web sites are listed in Table 3, however, how well these online labs satisfy the ABET engineering criteria has not been rigorously assessed or specifically addressed. This is an area for future research.

\begin{tabular}{|l|l|}
\hline Resource & Web site \\
\hline National University of Singapore & http://vlab.ee.nus.edu.sg/ \\
\hline Cyberlab & http://www.cyberlab.org/ \\
\hline University of Tennessee at Chattanooga & http://chem.engr.utc.edu/Webres/Stations/V-SINE.HTM \\
\hline LabMentors & http://labmentors.com \\
\hline Stevens Institute of Technology & $\begin{array}{l}\text { http://www.soe.stevens-tech.edu/Academics/remote_lab.html } \\
{[61]}\end{array}$ \\
\hline Chalmers University of Technology & http://www.ic.chalmers.se/ilab/ \\
\hline PEARL Project & http://kmi.open.ac.uk/projects/pearl/summary/index.htm \\
\hline Linkopings University & http://www.ida.liu/se/ her/npp/demo.html \\
\hline Lab-on-Web & http://www.lab-on-web.com \\
\hline University of Texas & http://www.robotics.utexas.edu/simulations/ \\
\hline Johns Hopkins University & http://www.jhu.edu/ virtlab/virtlab.html \\
\hline MIT & http://weblab.mit.edu/ \\
\hline
\end{tabular}

Table 3. Examples of online laboratory Web sites. All URLs were active as of October 2004. 


\section{ONLINE METHODS FOR ENGINEERING EDUCATION}

For online methods to become widely accepted as a standard part of engineering education delivery systems, a wide variety of elements need to be understood, promulgated, and accepted by the engineering professoriate, administrations, and students.

- Questions to be addressed by the professoriate include the following:

- How can we ensure that students will learn better in an online environment?

- What are the teaching strategies we need to understand that are different from the traditional classroom?

- Why would we want to teach online?

- How can we make the technology work?

- How do we decide which resources make sense to use for an online or an on-campus course? Are additional resources required?

Questions for engineering administrators are largely resource-driven; e.g.:

- What resources are necessary to serve the needs of online education? What will be the cost of maintaining a course management system? What are the best ways to support faculty?

- Are teaching loads increased, decreased, or the same if more online courses are taught?

- What are the trade-offs in faculty time devoted to instruction between online and on-campus teaching?

- Will faculty be satisfied teaching online?

- What will happen with student satisfaction, will it remain the same, improve, or deteriorate? What will parents say about their children taking online courses?

Students, of course, will be concerned about their academic experience:

- Will this online course count the same as the one on campus?

- Do we have to have special software to access the class?

- Can we work from home (or my dorm)?

- When do we have to participate?

- Will the degree or credential be the same as for on-campus students?

- Will we learn as much online as we would on campus?

\section{A. What We Need to Know}

1) Blending methodologies: Blended learning is sometimes defined as an optimal combination of face-toface and online education that improves learning and the satisfaction of instructors and students at a reasonable cost [62]. Blended education is touted as a means to (1) conserve classroom utilization, laboratory time, and effort, (2) create convenience by time shifting student and instructor learning, (3) improve learning through practices such as bringing distant experts into the classroom, or (4) organize groups of learners located in many different places [63]. Presently, it appears that blending is viewed as a means to bring online education into the core educational activity of college campuses.

Interesting research questions include the following: How much face-to-face time is needed to optimize learning, cost, and satisfaction? Does the amount of time vary by discipline and topic? Can one, for 
example, more easily teach computer coding online because of the easy sharing of computer code (as compared to a course requiring hands-on access)? How does one most effectively utilize available faceto-face time? How is optimization between online and face-to-face time achieved? What are the most advantageous combinations of blending methods and time [64]?

2) Teaching online via different pedagogies: How should different pedagogies be deployed online? The traditional lecture is no problem-it can be duplicated in a synchronous broadcast model in which lectures are viewed at the same time they are produced or recorded for later playback [65]. Synchronous online systems can permit nearly the same level of interaction as in typical classrooms. However, constructivist approaches are more difficult . What are the best ways to construct knowledge in teams, share, investigate, build, and present? The optimal ways to teach engineering are not well understood by almost any standard. Colleges such as Olin College [66] are experimenting with the so-called "do-learn" [67] paradigms in which students, from the outset, are thrust into "doing” (e.g., experimenting, designing, building) while "learning” what they need to know to be successful as they "do."

Stanford University has pioneered courses that engage students in the real world at a distance. For example, there has been a ten-year history of engaging graduate mechanical engineering students in work with corporate partners at a distance at Stanford [68, 69]. Courses focused on team-based design have made use of the Internet and other electronic tools, not only for implementing a geographically dispersed learning environment, but also for assessing performance outcomes. It has been shown that the overall quality of the designs produced by these distributed design teams stands up well to industry standards. Stanford has also been active in work on global learning with cross-disciplinary teams. The most ambitions of these efforts has been development of a problem-based learning course that engages architecture, structural engineering, and construction management students from universities in the United States, Europe, and Japan, including Stanford University; UC Berkeley; Cal Poly San Luis Obispo; Georgia Tech; Kansas University; Stanford Japan Center in Kyoto, Japan; Aoyama Gakuin University in Tokyo, Japan; University of Ljubljana in Slovenia; Bauhaus University in Weimar, Germany; ETH Zurich and FHA in Switzerland; Strathclyde University in Glasgow, United Kingdom; KTH in Stockholm, Sweden; and TU Delft in the Netherlands. The course engages faculty, practitioners, and students from different disciplines who are geographically distributed but connected through the Internet and other electronic media [70-72].

These types of learning activities for engineering work well and are thought to be a useful model for more robust implementations in online and/or blended venues. Nevertheless, many colleges subscribe to the "learn-do" paradigm, that is, learn all the things you need to know prior to applying the knowledge. The professoriate will not likely reach a decision in the near term about which of these methods (or combinations) is best.

3) Assessment: An early promise of technology was in the area of assessment of student learning and attitudes. Implementing easy ways to secure rapid feedback from students in the classroom (instant response indicators, for example) or measuring the use of materials (as done in course management systems) is commonplace. Surveys for formative assessment are less well used, at least in part because of the difficulty in creating surveys and motivating students to complete them. Some concerns have appeared about invasion of privacy (e.g., monitoring when a student does the homework) or matching work from students with other source materials in plagiarism-detection machines [73]. Instant interaction online works well in synchronous teaching tools (e.g., products like Webex, Elluminate, or Centra [74]) in which students can raise hands or vote online even though they are not collocated. 


\section{B. What We Need to Do}

1) Improve the quality of teaching and learning: Many studies have claimed no significant difference in test scores and satisfaction surveys between fully online and fully face-to-face courses $[75,76]$ although there are clearly problems in interpreting media differences [77]. Nevertheless, 75 percent of respondents (including faculty and administrators) to the Sloan Consortium 2003 survey indicated that they thought online learning would be better than on-campus instruction in three years [78]. Better in what way? Two possibilities are providing more convenience or producing learning outcomes that are better. Creating convenience is straightforward simply by introducing some number of online sessions in a typical engineering class. Not missing a classroom session by (a) attending remotely, (b) reviewing a recorded session, or (c) time shifting with an asynchronous session provides the simplest of conveniences. Introducing such convenience increases student satisfaction, as the traditional on-campus class becomes a blended mixture of face-to-face and online. More difficult is defining how online courses can provide stronger learning experiences. Learning outcomes can be improved using online techniques such as simulations [79], visits from remote luminaries, or providing cross-institution learning experiences that are online [80], as well as by improving continuous communication among students. The most significant gains will be in areas in which benefit is brought to the traditional classroom that could not have been secured without the online component.

One possible improvement with online capabilities is in teaching the basics. Providing self-paced modules to students allows additional time for participants in instructor-led courses to engage in interactive exercises. The use of self-paced modules and modules that reduce the amount instructor time for preparation can be found on sites such as Merlot [81] and NEEDS [82]. Experiments are currently in progress that could provide significant benefits to technology-based learning that might become part of a more complete online education package. For example, the Connexions [83] project provides a means of organizing knowledge that many people can access over the Web, including many reusable materials in electrical engineering.

2) Reduce costs: Cost reduction, while holding quality level and/or improving quality, can be achieved in various ways. Cost reductions can occur through providing excellent simulations, learning materials, and instructor guides that are used by many students. Many simulations already exist (e.g., the capstone business simulation [79]); a significant number of useful simulation materials are shared among faculty at such Web sites as Merlot [81] or NEEDS [82]. Reinventing ways to present materials, organize topics, build simulations, and test takes remarkable amounts of instructor time. Sharing and reusing materials should lower costs for course creation. More work on organizing methods to support teaching and learning through creating and promoting the use of excellent teaching materials will surely save valuable instructor time. The most valuable use of instructor time is in the organization of pedagogy and discussion with students. Other costs savings can be found in delivery and administrative areas [84].

3) Improve student satisfaction: Online education often improves the satisfaction of students by providing written learning frameworks on course Web pages or course management pages. Students who need stepby-step instructions can follow an explicit guide online. Similarly, students who wish to explore outside the confines of class instruction can be provided links to an expanded set of learning materials.

Other elements known to improve student satisfaction are: rapid feedback (easily provided by self-testing quizzes); time shifting; sense of community built from online discussions; assistive materials keyed to level of need; and improved peer-to-peer interaction (which will also impact quality positively). 
4) Improve faculty satisfaction: Two major keys to faculty satisfaction in online education are (1) understanding and utilizing online capabilities in a way that provides additional value to their academic lives and (2) recognition. The first key may be realized in multiple ways; for example, increasing the ability and competence of students while using time more effectively. The second key is for faculty to improve their teaching through online methods and receive greater recognition, both from students and from their administration. Online materials can provide real gains in knowledge organization and reduce the amount of time needed to organize a course over repeated semesters. Taken in combination, the online teaching experience can be more satisfying for faculty.

5) Provide mathematics and design capabilities: One key to adopting online methods in engineering education is to provide engineering instructors the capability of using mathematics and design tools easily at a distance. Popular course management systems provide equation editors, and many other products exist [85]. Equations often can be displayed in slides, via text-created documents, or embedded in text documents posted in discussion or content areas of course support systems. However, none of the solutions created provide the ease of physically writing or sketching on a blackboard (or white board). Tablet PCs provide one way of solving the writing and sketching problem, but still only approach the use of the physical blackboard. Online handwriting recognition [86] is still not in the mainstream, but could well become more widely employed in online education. Similarly, improvements to online design tools that permit students to easily create system diagrams, including electronic and mechanical designs, will assist in the acceptance of online education in the mainstream of engineering education. For example, current online electronic design automation (EDA) tools typically require large files, creating some level of difficulty in sharing designs [87]. However, shared viewers, collaboration tools, and the ability to import and export between tools will assist in integrating online learning and engineering design.

Various other tools may provide improvements as well. For example, concept maps [88, 89] have the ability to provide shared collaborative, graphic environments across the global network. The capability of concept maps to support shared brainstorming, discussion, and visualization provides interactivity that has not been readily available online.

6) Create better laboratory facilities for online engineering education: There are currently two approaches to implementing online labs. The first is the use of Web-based simulations, sometimes referred to as virtual labs. Educational simulations have been shown to be equivalent to physical labs for explaining and reinforcing concepts [90]. As an interactive experience, there is little reason why simulations cannot serve to meet several of the ABET engineering competencies. Simulations provide some, but limited, capability for experimentation. On the other hand, as limited computational experiences, they cannot always accurately demonstrate the application of theory or concepts to the physical world. Although simple simulations are relatively inexpensive, the cost rises dramatically as the simulation more closely models the physical world. Educational simulations have typically been limited in scope and accuracy. In contrast, simulations (e.g., for electronic design) used in industrial practice for verifying designs and checking faults are orders of magnitude more expensive than educational simulations [87].

The second approach is use of the Internet to allow students to manipulate and observe real equipment and instrumentation located at a distance [91, 92]. This approach is often referred to as remote labs. Remote labs deal with real phenomena and equipment and can be used to build skill as well as knowledge [93]. It appears certain that virtual and remote labs will gradually replace some traditional on-campus labs and supplement others. In online education, these anytime, anywhere labs will become increasingly common [94-96]. It remains to be seen, however, if they will be accepted to the extent needed to make fully online undergraduate engineering degrees possible. 
7) Allow students to be virtually away: Students at traditional college campuses often operate in the "bubble" of not knowing what goes on in the outside world. This observation is especially true for engineering students. Many colleges provide experiences away in which students can experience other cultures or other campuses, for example, during a junior year abroad. Unfortunately, most engineering students are not able to take advantage of such experiences because of the multiple required courses or electives that must be fulfilled. Fortunately, online education can provide some of the desired worldconnectivity experiences. For example:

- Students can take online courses at other institutions. Taking courses in topics not offered at an institution is one clear way to provide an experience away to students. Another method is to provide some blending by actually sending students to spend a short time at a remote college offering the online course.

- Collaborative teams can be formed across institutions [97]. Teams of students at multiple institutions conducting projects together via the Internet can provide a real-world learning experience similar to post-matriculation work.

- Virtual internships can be offered. In a blended virtual internship, students can join global teams in industry to work on real problems.

- Remote experts can be brought to the blended classroom. The easiest way to add value rapidly to a blended environment is to add remote discussants to an online classroom experience.

- Students can go on study tours, for example abroad, and continue to take courses at their home institutions.

8) Create partnerships: Partnerships represent an underutilized capability for online engineering education that has the potential to change the educational process. The concept is to organize scarce resources at multiple colleges to provide much more than can be done in a single specialty at a single college. The National Science Foundation recognized the discipline organization strategy by creating the VaNTH Biomedical Engineering consortium in 1998, which links multiple universities in the biomedical engineering discipline [98]. While not specifically focused on online organization, this consortium points the way toward linked specialty areas in engineering education that can benefit from online methodologies.

9) Use technology for online learning: Much has been written on the use of information technology in engineering education (see review [99]). Using a variety of these technologies, ranging from high-speed connectivity to course management systems, can assist that will facilitate learning engineering that cannot be done without technology? Table 4 outlines examples that illustrate how technology permits the implementation of online paradigms that would be difficult without technology and how each of these examples affects quality, scale, and breadth.

\begin{tabular}{|l|l|l|}
\hline \multicolumn{1}{|c|}{$\begin{array}{c}\text { Activity made possible or } \\
\text { improved through use of } \\
\text { technology }\end{array}$} & \multicolumn{1}{|c|}{$\begin{array}{c}\text { Technology implementation } \\
\text { method }\end{array}$} & \multicolumn{1}{c|}{$\begin{array}{c}\text { Potential Effects: Quality, } \\
\text { Scale, Breadth }\end{array}$} \\
\hline $\begin{array}{l}\text { Student teams collaborate across } \\
\text { multiple institutions }\end{array}$ & $\begin{array}{l}\text { Internet and multiple TCP/IP } \\
\text { enabled technologies, both } \\
\text { synchronous and asynchronous }\end{array}$ & Quality, scale and breadth \\
\hline $\begin{array}{l}\text { Robust game-playing simulations } \\
\text { across institutions [100] }\end{array}$ & Simulation software & Quality \\
\hline $\begin{array}{l}\text { Remote laboratories and } \\
\text { instruments }\end{array}$ & Remote control via the Web & Quality and scale \\
\hline
\end{tabular}




\begin{tabular}{|l|l|l|}
\hline Tracking student work & $\begin{array}{l}\text { Course management systems } \\
\text { track student work }\end{array}$ & Quality \\
\hline $\begin{array}{l}\text { Organization and display of } \\
\text { student work, portfolios }\end{array}$ & Web-based portfolios & Quality \\
\hline Remote experts & $\begin{array}{l}\text { Use of synchronous tools for } \\
\text { bringing experts live to a class }\end{array}$ & Quality \\
\hline $\begin{array}{l}\text { Courses delivered from one } \\
\text { college to another }\end{array}$ & Web-based & Scale \\
\hline $\begin{array}{l}\text { Providing courses to distant and } \\
\text { distributed learner populations }\end{array}$ & Web via the Internet & Scale \\
\hline $\begin{array}{l}\text { Self-paced modules, including } \\
\text { shared modules (e.g., Merlot } \\
\text { [81]) }\end{array}$ & $\begin{array}{l}\text { Various technology tools are } \\
\text { available to package self-paced } \\
\text { courses }\end{array}$ & Scale and breadth \\
\hline $\begin{array}{l}\text { Capturing lectures for } \\
\text { asynchronous delivery }\end{array}$ & Streaming video, audio & Scale \\
\hline
\end{tabular}

Table 4. Technology-enhanced learning in online environments.

\section{MOVING TOWARD THE FUTURE: THE ART-OF-THE-POSSIBLE}

What can be done to enable all levels of students to learn engineering anywhere, anytime in the upcoming decades? Is it possible to create learning environments where students can take degrees either online or on campus, at their convenience, with quality, scale, and breadth? This situation exists at the master's level but not yet at the undergraduate level. To create more pervasive online learning for undergraduate engineering education, several drivers are needed to move engineering colleges more toward online education. Drivers include the need to (1) populate classes (a driver for colleges that struggle to capture more market share), (2) provide more education with a limited space (a driver for colleges that have more demand than capacity), (3) provide more flexibility for teaching staff, (4) satisfy students who demand the capability of learning anywhere and at anytime, (5) serve populations of lifelong learners, (6) drive down costs while keeping quality high, (7) solve parking and commuting problems, and (8) reach world populations of learners.

It is likely that the first movement toward more online learning will come in blended environments in which courses are offered on campus but with a significant online component. With sufficient incentives, there may also be a parallel movement to offer complete engineering degrees online. An example of an incentive is the creation of partnerships among institutions to deliver curriculum and or instruction. Examples of partnerships are the Western Governors University [101], a nonprofit online university founded by the governors of nineteen western states that is designed to provide competency-based education; and eArmyU [102], a U.S. Army program that supplies education to soldiers from a group of some thirty institutions. If blended education is accepted in engineering education and widely utilized, there will likely be many opportunities for quality improvement through partnerships, curriculum sharing, cross-institutional instruction, and so forth. However, a large number of other problems are arising in technical, political, social, and regulatory areas.

\section{A. The Blended World}

Online methods are likely to become component elements of teaching and learning in engineering education as faculty and students become aware of and utilize facets of online education that improve 
quality, scale, and breadth. Some will seek quality improvements by demonstrating improved learning with similar amounts of effort as face-to-face; others will demonstrate that more students can be engaged in learning and that learners that could not be reached before are now being reached. Experiences of individuals who can do something with online methods that they could not do before will be key to moving online education toward the mainstream of engineering pedagogy. "Grass roots" growth will likely characterize online/blended scenarios in engineering education. Currently, there are no compelling drivers that suggest the changes will be rapid. Indeed, quite the opposite may be true-given the growth in the populations of learners in the upcoming decade, there may be little incentive to change from the norm. Several factors, however, may impact the timeline of change.

\section{B. Impact Factors}

Various factors are likely to have an impact on the future of online engineering education. Political, economic, social, and technology factors will have their own particular impact. For example, the political impact could be great, as decisions are made about whether students who attend completely online degree programs can receive federal financial aid or whether online programs are accredited in acceptable ways. Pricing online education will likely be a touch-point of controversy. Some institutions charge more for an online course than an equivalent on-campus course. However, the natural linking of branding to pricing will likely continue until pressures become too great to sustain the continuing upward tuition pricing spirals. It is predictable that at some point lower-priced suppliers will come forward to offer acceptable degrees. In fact, various online for-profit institutions currently offer degrees that compete at some level with traditional degrees. Technology will clearly have an impact on the future of online engineering education. As technology improves, many of the difficulties with delivering online engineering education will disappear. For example, virtual laboratories and access to non-collocated laboratories will become more routine, as will the ability to build collaborative educational programs among institutions. Ultimately, all of these factors will have an impact on the social structure of the United States, as citizens will have the ability to access learning anywhere and at anytime at the institution of their choosing.

\section{Online Rivalries and Partnerships}

Will online engineering education increase or decrease competition among colleges? Will natural partnerships arise or will colleges remain insular? Consider the five forces diagram in Figure 2. Rivalry could increase because of new entrants or coalitions of colleges. For-profit education suppliers also represent a potential force. In this model, both faculty and students have increased bargaining power and can shift easily among colleges. Faculty can teach at any college and never leave their physical location in an all-online world. Students will also have equal access. If courses and materials become standardized across suppliers, rivalry may intensify along a high-touch axis (i.e., a student-faculty interaction axis). There may be increased competition among shifting coalitions of educational suppliers and consumers at the college level. The threat of rivalry may cause partnerships to emerge. It is tempting to believe that the status quo will continue; however, online education has the potential to disrupt—it is worth being ready. 


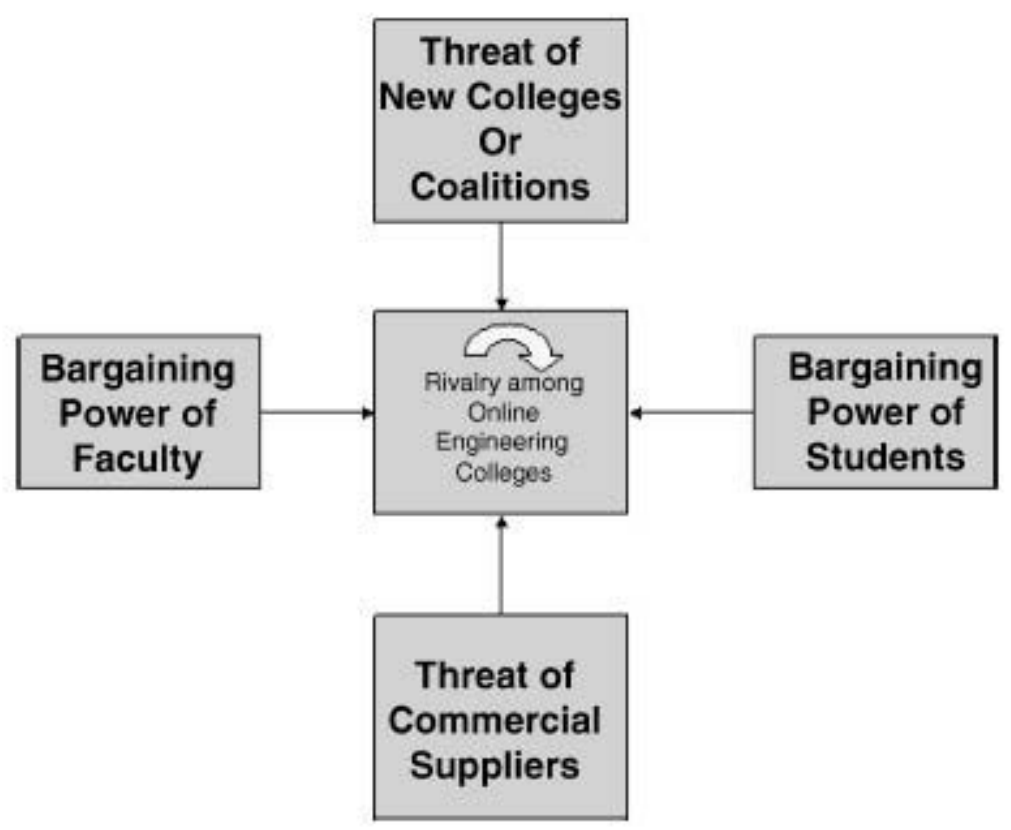

Figure 2. Forces causing rivalry among engineering colleges [103].

\section{TRENDS AND RECOMMENDATIONS}

As online education becomes an everyday part of engineering education, the following trends should become evident.

\section{A. Trends}

The quality of online teaching and learning in engineering will steadily improve during the upcoming years as teaching and learning technologies improve, including the use of better simulations and course management tools. In addition, quality will be improved through the introduction of more interactive, engaging learning experiences, including constructivist methodologies.

- Online methods in engineering education will increase the breadth and scale of engineering education, thus extending the reach of institutions and the delivery of education to broader audiences.

- Specialty areas will leverage expertise among institutions, thus driving down the cost of replicating facilities at multiple institutions.

- The quality of engineering education output (the engineering graduate prepared according to ABET standards) can be dramatically improved through collaboration among institutions. Online methodologies can be the driver that enables collaboration.

- Materials for engineering education can be utilized across institutions, thus increasing quality and driving down costs. Analogous to books that reach multiple institutions, simulations, computerbased training materials, and even course management systems can also be developed in collaboration.

- Engineering education offered in a blended format is likely to become much more prevalent during the upcoming years. Engineering education will be offered with a range of blended percentages, ranging from all-online to all-classroom instruction. 
- As students and faculty become accustomed to the benefits of teaching and learning in an online or blended modality, both will demand the opportunity to teach and learn online.

\section{B. Recommendations}

We recommend that engineering colleges explore, implement, and extend blended learning and partnership activities and continue to build-out the use of technology implementations that increase the quality of online courses, improve our ability to scale to larger populations, and improve the breadth of coverage of engineering courses. The collection of data and distribution of knowledge about successes and failures will permit scaffolding across the spectrum of colleges and universities engaged in online engineering education over the upcoming decade.

\section{ACKNOWLEDGMENTS}

The continuing generous support of the Alfred P. Sloan Foundation is acknowledged. Support of Olin and Babson Colleges is acknowledged, as well. The authors wish to thank Janet Moore for her work on the Sloan-C Catalog, which was used to produce the tables in this paper. Thanks go to Elaine Allen and Jeff Seaman for data from the Sloan-C survey. We also thank Stephen Schiffman and Sherra Kerns of Olin and Babson Colleges for their careful reading of the manuscript. We thank Kathryn Fife for formatting assistance and Stephanie White of the Olin College library for assistance in finding references. Finally, we appreciate the comments from several anonymous reviewers and from the editors who assisted in improving the contents of this paper.

\section{REFERENCES}

1. http://www.sloan-c.org.

2. Gomory, R. E. Sheffield Lecture-Yale University, January 11, 2001, Internet Learning: Is it real and what does it mean for universities? Journal of Asynchronous Learning Networks 5 (1): 193146, 2001.

3. Mayadas, A. F. Testimony to the Kerrey Commission on Web-Based Education. Journal of Asynchronous Learning Networks 5 (1): 134-138, 2001.

4. http://www.sloan.org/programs/edu_careers.shtml\#.

5. Allen, I. E., and J. Seaman,. Sizing the Opportunity: The Quality and Extent of Online Education in the United States, 2002 and 2003, Needham, MA.: Sloan-C, 2003. Online:

6. http://www.sloan-c.org/resources/sizing_opportunity.pdf.

7. As measured by the number of catalog entries in the Sloan-C Catalog of online degree programs.

8. http://www.nsf.gov/od/lpa/newsroom/pr.cfm?ni=90.

9. Grose, T. K. Can Distance Education be Unlocked? Prism 12 (8): April 19-23, 2003. Available online: http://www.prismmagazine. org/april03/unlocked.cfm.

10. Peterson, G. D., and L. D. Feisel. e-Learning: The Challenge for Engineering Education. Proceedings, e-Technologies in Engineering Education, A United Engineering Foundation Conference, 164-169. Davos, Switzerland, 11-16 August, 2002. Online:

11. http://services.bepress.com/eci/etechnologies/.

12. Journal of Asynchronous Learning Networks (JALN), online: http://www.sloanc.org/publications/jaln/index.asp.

13. Bitzer, D. The Wide-World of Computer-Based Education. Advances in Computers 15: 239, 1976.

14. Shacham, M., and M. B. Cutlip. Computer-based Instruction: Is There a Future in ChE Education? Chemical Engineering Education 15 (2): 78, 1981.

15. Bourne, J., A. Mayadas, and J. Campbell. Asynchronous Learning Networks: An InformationTechnology-Based Infrastructure for Engineering Education. Proceedings of the IEEE 88 (1): 2000. 
16. Grose, T. K. Distance Education the UK Way. Prism: November 26-29, 1999.

17. "Effective Practices for Cost Effectiveness: Methods for Conserving Costs, Time, Effort." Sloan-C Effective Practices, online: http://www.sloan-c.org/ effective/SortByCostE.asp.

18. Sloan-C Series: Books on Online Education, http://www.sloan-c.org/ publications/books/index.asp.

19. Anderson, L. P., and C. A. Kent. Interactive Televised Courses. College Teaching 50 (2): 67-74, 2002.

20. Kolar, R. L., D. A. Sabatini, and L. D. Fink. Laptops in the Classroom: Do They Make a Difference. Journal of Engineering Education 91 (4): 397-401, 2002.

21. Ellis, T. Animating to Build Higher Cognitive Understanding: A Model for Studying Multimedia Effectiveness in Education. Journal of Engineering Education 93 (1): 59-64, 2004.

22. Merino, D., and K. Abel. Evaluating the Effectiveness of Computer Tutorials Versus Traditional Lecturing in Accounting Topics. Journal of Engineering Education 92 (2): 189-194, 2003.

23. Richardson, J. C., and K. Swan. Examining Social presence in Online Courses in Relation to Students' Perceived Learning and Satisfaction. Journal of Asynchronous Learning Networks 7 (1): 68-88, 2003.

24. Gold, S. A Constructivist Approach to Online Training for Online Teachers. Journal of Asynchronous Learning Networks 5 (1): 35-57, 2001.

25. Moore, J. C. Elements of Quality: The Sloan-C Framework. Needham, Mass.: Sloan-C, 2002.

26. http://www.asee.org/neic/engeducation/usauniv.cfm.

27. Sener, J., and M. Stover. An AS Engineering Degree Program via ALN. Proceedings, Frontiers in Engineering Conference, 1997. Online: http://fie.engrng. pitt.edu/fie97/papers/1425.pdf

28. Mosterman, P. J., M. A. M. Dorlandt, J. O. Campbell, C. Burow, R. Bouw, A. J. Brodersen, and J. R. Bourne. Virtual Engineering Laboratories: Design and Experiments. Journal of Engineering Education 83 (3): 1994.

29. Mosterman, P. J., J. O. Campbell, A. J. Brodersen, and J. R. Bourne. Design and Implementation of an Electronics Laboratory Simulator. IEEE Transactions on Education 39 (3): 309-313, 1996.

30. Dutton, J. A. e-Education Institute, College of Earth and Mineral Sciences, Pennsylvania State University, Personal communication, 2004.

31. Spak, G. New Jersey Institute of Technology, Personal communication, February 22, 2004.

32. Miller, G. Pennsylvania State University, Personal communication, February 22, 2004.

33. Frederick, K. Personal communication, January 2004.

34. Shelley, P. Advanced Distance Learning Network, Worcester Polytechnic Institute.

35. http://www.sloan-c.org/programs/index.asp.

36. Szatmary, D. University of Washington, Personal communication, February 2004.

37. http://www-epgy.stanford.edu.

38. The National Center for Educational Statistics, http://nces.ed.gov, 2004, reports that over the last half century the proportion of Bachelors to Masters degrees has varied from 10/1 (50 years ago) to about 4/1 (today).

39. See mathematics tool in Elluminate, for example, http://www.elluminate.com.

40. For an example of a remotely controlled lab, http://chem.engr.utc.edu/.

41. Ross, S., and E. Scanlon. Open Science: The Distance Teaching and Open Learning of Science Subjects, Paul Chapman Publishing, 1995.

42. Technology Accreditation Commission Report, online:

43. http://www.abet.org/documents/tac/tc004 pev report 7-15-03.doc.

44. http://edcorner.stanford.edu/index.shtml.

45. For example, the Olin College experience, http://www.olin.edu.

46. Spencer, D. Computer-mediated Communications: State of the Art. Group Facilitation. Collaboration and Asynchronous Learning Networks, December 2000.

47. Online: http://web.njit.edu/ hiltz/CMC_SOTA_David.doc.

48. http://www.moodle.org. 
49. Coward, H. R., C. P. Ailes, and R. Bardon. Progress of the Engineering Education Coalitions, Final report. SRI International, May 2000. Online: http://www.nsf.gov/pubs/2000/nsf00116/nsf00116.txt.

50. Seymour, E. Why Undergraduates Leave the Sciences. Westview Press, 1997.

51. Gunn, C., M. McSporran, H. Macleod, and S. French. Dominant or Different? Gender Issues in Computer Supported Learning. Journal of Asynchronous Learning Networks 7 (1): 13-30, 2003.

52. "Lifelong Learning in the Global Knowledge Economy: Challenges for Developing Countries," Publication 26001, Washington D.C.: The World Bank, May 2003.

53. http://apm.stanford.edu.

54. https://engineering.purdue.edu/CEE.

55. Meister, J. C. The Brave New World of Corporate Education. The Chronicle of Higher Education, February 9, 2001.

56. http://mu.motorola.com.

57. http://cisco.netacad.net/public/academy/.

58. http://www.semizone.com.

59. Feisel, L. D., and A. J. Rosa. The Role of the Laboratory in Undergraduate Engineering Education. Journal of Engineering Education 94 (1): 121-130, 2005.

60. Chang, V., and. J. A. del Alamo. Collaborative WebLab: Enabling Collaboration in an Online Laboratory. World Congress on Networked Learning in a Global Environment, Berlin (Germany), 2002.

61. Steinemann, M. A., and T. Braun. Remote Versus Traditional Learning in a Computer Networks Laboratory. Communications and Computer Networks, 503-507, Cambridge Mass., 2002.

62. Fernandez R., E. Kinguti, and F. Ramirez-Fernandez. A Virtual Laboratory to Perform Electronic Experiments by Internet. 2002 International Conference on Engineering Education, Manchester, U.K.

63. Saliah-Hassane, H., P. Dumont-Burnett, and C. Kedowide. A Framework for a Distributed Measurement User Interface. 2002 International Conference on Engineering Education, Manchester, U.K.

64. Söderlund, A., F. Ingvarson, P. Lundgren, and K. Jeppson. The Remote Laboratory-A New Complement in Engineering Education. 2002 International Conference on Engineering Education, Manchester, U.K.

65. Note: in this URL, remote and lab are separated by an underscore.

66. Other complementary definitions include: blending of content materials, blending of totally online and totally face-to-face courses to constitute a degree program, blending of delivery methods and blending of courses across institutions.

67. Reasons, S. Questioning the Hybrid Model: Student Outcomes in Different Course Formats. Journal of Asynchronous Learning Networks, forthcoming.

68. "Advantageous" may be defined as any set of metrics - this paper uses the term in the context of the five pillars described earlier in the paper.

69. http://www.elluminate.com.

70. http://www.olin.edu.

71. Term coined by Woody Flowers at Olin College in 2001.

72. http://me310.stanford.edu.

73. Leifer, L. Design Team Performance, Metrics and the Impact of Technology. In Evaluating Corporate Training: Models and Issues, Brown, S. and C. Seidner, eds., 1-22. Kluwer Academic Publishers, 1998.

74. Fruchter, R., and A. Townsend. Multi-cultural Dimensions and Multi-Modal Communication in Distributed Cross-Disciplinary Teamwork. International Journal of Engineering Education 19 (1): 53-61, 2003.

75. Fruchter, R. Global Teamwork: Cross-disciplinary, Collaborative, Geographically Distributed eLearning Environment. In Collaborative Design and Learning: Competence Building for 
Innovation, Benito, J., J. Duarte, M. Heitor, and W. Mitchell, eds. Quorum Books, Greenwood Publishing Group, Inc., 2002.

76. Fruchter, R. Architecture/Engineering/Construction Teamwork: A Collaborative Design and Learning Space. Journal of Computing in Civil Engineering 13 (4): 261-269, October 1991.

77. http://www.plagiarism.org.

78. http://www.webx.com, http://www.elluminate.com, http://www.centra.com.

79. University of Phoenix, http://www.sloan-c.org/effective/details3.asp?LE_ID=17.

80. Grandzol, J. R. Enabling Student Learning in the Online Environment. Proceedings, 2003 9th Annual Sloan-C Conference.

81. Online: http://www.sloan-c.org/conference/proceedings/2003/pdf/1702.pdf.

82. Joy, E.H. Measuring Learning Effectiveness: A New Look at No-Significant-Difference Findings. Journal of Asynchronous Learning Networks 4 (1): 33-39, June 2000.

83. http://www.sloan-c.org/resources/survey.asp.

84. Example, http://www.capsim.com.

85. Theroux, J. Experimental Online Case Study Aims for a Breakthrough in Student Engagement: Description and Results. Journal of Asynchronous Learning Networks 8 (4): Fall 2004, in press.

86. http://www.merlot.org.

87. http://www.needs.org.

88. http://cnx.rice.edu.

89. Rumble, G. The Costs and Costing of Networked Learning. Journal of Asynchronous Learning Networks 5 (2): 75-96, 2001.

90. For example, MathType http://www.dessci.com.

91. Lopresti, D. P., R. Plamondon, L. Schomaker, and R. Srihari. On-Line Handwriting Recognition. Wiley Encyclopedia of Electrical and Electronics Engineering 15: 132-146, 1999.

92. Birnbaum, M. D. Electronic Design Automation (EDA), Prentice Hall, 2004.

93. http://cmap.ihmc.us.

94. Coffey, J. W., and A. J. Cañas. LEO: A Learning Environment Organizer to Support ComputerMediated Instruction. Journal for Educational Technology Systems 31 (3): 275-290, 2003.

95. Campbell, J. O., J. R. Bourne, P. Mosterman, and A. J. Brodersen. The Effectiveness of Learning Simulations for Electronic Laboratories. Journal of Engineering Education 91 (1): 81-87, 2002.

96. Fjeldly, T. A., and M. S. Shur, eds. Lab-on-the-Web, Running Real Electronics Experiments via the Internet, New York, N.Y.: John Wiley \& Sons, 2003.

97. Del Alamo, J. A., L. Brooks, C. McLean, J. Hardison, G. Mishuris, V. Chang V., and L. Hui. The MIT Microelectronics WebLab: A Web-Enabled Remote Laboratory for Microelectronic Device Characterization. 2002 World Congress on Networked Learning in a Global Environment, Berlin Germany.

98. Faltin, N., A. Böhne, J. Tuttas, and B. Wagner. Distributed Team Learning in an InternetAssisted Laboratory. 2002 International Conference on Engineering Education, Manchester, U.K.

99. Esche, S. K. Remote Experimentation-One Building Block in Online Engineering Education. Proceedings of the 2002 ASEE/SEFI/TUB International Colloquium on Global Changes in Engineering Education, Berlin, Germany, October 1-4, 2002.

100. Henry, J., and C. Knight. Modern Engineering Laboratories at a Distance. International Journal of Engineering Education 19 (3): 2003.

101. Campbell, J. O., J. R. Bourne, P. J. Mosterman, M. Nahvi, R. Rassai, A. J. Brodersen, and M. Dawant. Cost-Effective Distributed Learning with Electronics Lab. Journal of Asynchronous Learning Networks 8 (3): 5-10, 2004.

102. Gay, G., and M. Lentini. Use of Communication Resources in a Networked Collaborative Design Environment. Journal of Computer-Mediated Communication 1 (1): 1995.

103. Online: http://www.ascusc.org/jcmc/vol1/issue1/IMG_JCMC/ResourceUse.html.

104. http://www.vanth.org. 
105. Kadiyala, M., and B. L. Crynes. A Review of Literature on Effectiveness of Use of Information Technology in Education. Journal of Engineering Education 89 (2): 177-189, 2000.

106. Bisson, B., E. Leach, T. Little, R. Richards, B. Veitch, and K. Zunkel. A Case Study in Blended Learning: Leveraging Technology in Entrepreneurship Education. In: Elements of Quality Proceedings of the 2004 Summer Research Workshop, Sloan-C, 2004, in press.

107. http://www.wgu.edu.

108. http://www.earmyu.com.

109. Porter, M. E. Competitive Advantage: Creating and Sustaining Superior Performance, New York, N.Y.: The Free Press, 1985.

\section{AUTHORS' BIOGRAPHIES}

Dr. John R. Bourne is professor of electrical and computer engineering at the Franklin W. Olin College of Engineering and Professor of Technology Entrepreneurship at Babson College. He is executive director of the Sloan Consortium and editor of the Journal of Asynchronous Learning Networks. He is a fellow of the IEEE, a fellow of the American Institute for Medical and Biological Engineers, and editor of the Critical Reviews in Biomedical Engineering. He spent thirty-one years on the faculty at Vanderbilt University before joining Olin College as a founding faculty member in $2000 \mathrm{He}$ is the recipient of the Sloan-C Outstanding Achievement Award (2001) and the IEEE EAB Meritorious Achievement Award (2003).

Address: Olin Way, Olin College, Needham, MA 02492; telephone: (781) 292-2521; fax: (781) 2922505; e-mail: john.bourne@olin.edu.

Dale A. Harris is professor of engineering education and executive director of Continuing Engineering Education at Purdue University. Prior to Purdue, he has held academic positions at Harvard Medical School, Cal Tech, Stanford, Hokkaido University, and the University of Phoenix. He has held industry positions with the Department of the Army, Bank of America, and Pacific Bell. He is active within several professional organizations, including the New York Academy of Sciences, the IEEE, and the Alfred P. Sloan Consortium on Asynchronous Learning. Dr. Harris has served on the Board of Governors of the IEEE Communications Society and as the society's education director. He currently advises and consults for several start-up companies and previously was chairman of the board of LabMentors, a company providing e-learning services supporting hands-on laboratory training over the Internet.

Address: Potter 354, 500 Central Drive, Purdue University, West Lafayette, IN 47907; telephone: (765) 494-0212; e-mail: harris@purdue.edu.

Dr. A. Frank Mayadas is program director at the Sloan Foundation, where he is involved in a number of areas: online education, globalization of industries, industry studies, and career choice in technical fields. He started the Sloan online learning program in 1993. This program (known as Asynchronous Learning Networks or ALN) has had a profound impact on moving the field forward. Dr. Mayadas has been a keynote speaker at many distance education conferences and has testified before Congress on Web-based learning. He is a fellow of the IEEE and recipient of the Sloan-C Medal of Honor.

Address: Suite 2550, 630 Fifth Avenue, New York, NY 10111; telephone: (212) 649-1642; e-mail: mayadas@sloan.org.

*This article was originally published in the Journal of Engineering Education, Vol. 94, No. 1, January 2005, pp. 131-146. 
